\title{
凍結乾燥筋原繊維タンパク質の变性に及ぼす相対湿度の影響
}

\author{
松田由美子
}

(1982 年 8 月 4 日受理)

Influence of Relative Humidity on the Protein Denaturation of Lyophilized Carp Myofibrils during Storage

\section{Yumiko MatsUda*}

\begin{abstract}
The influence of relative humidity $(\mathrm{RH})$ on the quality change of lyophilized carp myofibrils during storage was estimated. Carp myofibrils were ground with polyphosphates and sucrose. The mixtures were freeze-dried at 60 or $35^{\circ} \mathrm{C}$, ground into powder, and stored in desiccators and over saturated salts slurries and other materials with constant relative humidities. Moisture sorption isotherms for lyophilized carp myofibrils were determined by drying those stored for ten days in desiccators. At suitable intervals, aliquots of the powders were taken out and examined as to the quality, using as indexes: solubility in $0.6 \mathrm{M} \mathrm{KCl}$, relative viscosity and ATPase activity of $0.6 \mathrm{M} \mathrm{KCl}$ extractable protein, and the total ATPase activity.

The results for powders with RH 10 to $98 \%$ stored at room temperature of 15 to $18.8^{\circ} \mathrm{C}$ for 6 months indicated that the lower the humidity, the better was the quality retention of the powder. In RH 10 to $15 \%$ there was no significant difference in the effect of RH. A second experiment studied RH 0 to $20 \%$ the qualities of powders stored in the RH below $15 \%$ were acceptable for 1 year at $20^{\circ} \mathrm{C}$. The last experiment was concerned with RH 0 to $20 \%$ at a high temperature of $35^{\circ} \mathrm{C}$; here, storing in the $\mathrm{RH}$ below $10 \%$ gave the qualities which were acceptable for a storage period of 6.5 months. Thus it was shown that the lyophilized myofibrils were stable even in the moisture range of free from monolayer moisture.
\end{abstract}

先の実験結果 13 から魚粉のかまほこ形成能力を保持す る上で包装が重視されるべき要因と示唆された。包装は 主に環境因子中の湿度と酸素との影響にかかわってい る。

本報ではコイ筇原瀻維の凍結乾燥による貯蔵に対し優 れた保護效果を持つと先に2) 明らかにしたスクロースと ボリリン酸塩添加采の凍結凯燥粉末を用い，各相対湿度 (RH) に眝蔵し，長期貯蔵安定珄を計る上での最適 RH を求めることを目的として実験を行った。

既に記載1)したように環境湿度は残存水の存在状態を 左右し，単分子層の水が存在する水分域に安全域がある といら考党がなされている。本報ではまずRH!10～98\% の広い湿度域について，寅温で険討し，安全域が低 RH にあることを諗め，次いで RH 0 20\%，20 C で，更 に高温下での詝蔵を考え RH 0 20\%，35 C で棟結乾 燥コイ筋原瀻維の安定域を検討した。

$$
\begin{array}{ll}
\text { 実 験 I } \\
\text { 方 }
\end{array}
$$

コイ筋原織維の調製捛よび各種分析は前報 ${ }^{2)}$ と同様に
行った。試料にスクロース $4 \%$ とポりリン酸塩（ピロリ ン酸ナトリウムとトリリン酸ナトリウムを等量混合した もの; PP) $0.16 \%$ 源加混合後の筋原繊維の水分, 粗脂 肪，粗タンパク質，粗灰分はそれぞれ 87.9，0.4，6.3， $1.1 \%$ であった。凍結および板温度 $60^{\circ} \mathrm{C}$ での倲結乾燥 中の品温の変化を Fig. 1 に示す。乾燥には 15 時間を 要しだ。

粉末はシャーレに薄く拡げ，あらかじめ無機塩類のス ラリーによって RHを Table 1 のよらに 10 98\%の 間で 8 段階に調整して和いたデシケータに入れ，15 $18.8^{\circ} \mathrm{C}$ の室温で貯蔵した。各 RH 10 日間貯蔵後の 粉末中の水分量を常王加熱乾燥法で測定し, Fig. 2 に示 さような収着等温線を得た。

Table 1 には $20^{\circ} \mathrm{C}$ K护る RH を表示してある。 射蔵は $15 \sim 18.8^{\circ} \mathrm{C}$ で行い，Fig. 2 には $15^{\circ} \mathrm{C}$ における 収着等温楾を示してある。温度による RH の補正は式) による計算る行われるが，中性塩類特有の昅着熱の特性

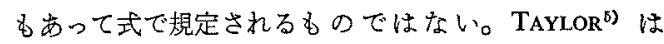
RH の温度への依存が小さいので食品を貯藏する温度範 团ではRHの補正は必要ではないと述べている。

\footnotetext{
* 東京水産大学 (Tokyo University of Fisheries, Konan, Minato, Tokyo 108, Japan).
} 


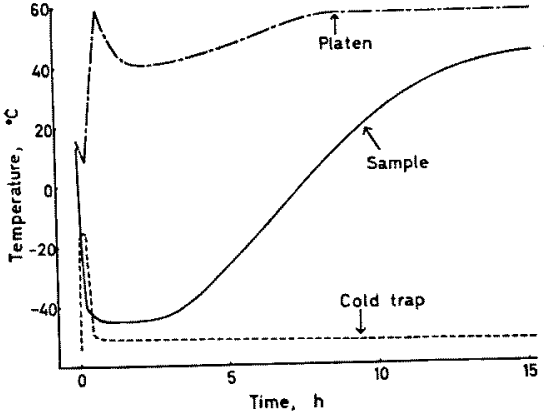

Fig. 1. Change in temperature during vaccumfreezing and subsequent lyophilization of myofibrils containing sucrose and PP.

Table 1. Saturated salt solutions for maintaining constant relative humidity at $20^{\circ} \mathrm{C}$

\begin{tabular}{lc}
\hline Solid phase & Humidity \\
\hline $\mathrm{ZnCl} \cdot 1 \frac{1}{2} \mathrm{H}_{2} \mathrm{O}$ & $10 \%$ \\
$\mathrm{LiCl} \cdot \mathrm{H}_{2} \mathrm{O}$ & $15 \%$ \\
$\mathrm{CH}_{3} \mathrm{COOK}$ & $20 \%$ \\
$\mathrm{CaCl}_{2} \cdot 6 \mathrm{H}_{2} \mathrm{O}$ & $32.3 \%$ \\
$\mathrm{Zn}\left(\mathrm{NO}_{3}\right)_{2} \cdot 6 \mathrm{H}_{2} \mathrm{O}$ & $42 \%$ \\
$\mathrm{NaBr} \cdot 2 \mathrm{H}_{2} \mathrm{O}$ & $58 \%$ \\
$\left(\mathrm{NH}_{4}\right)_{2} \mathrm{SO}_{4}$ & $81 \%$ \\
$\mathrm{CaSO}_{4} \cdot 2 \mathrm{H}_{2} \mathrm{O}$ & $98 \%$ \\
\hline
\end{tabular}

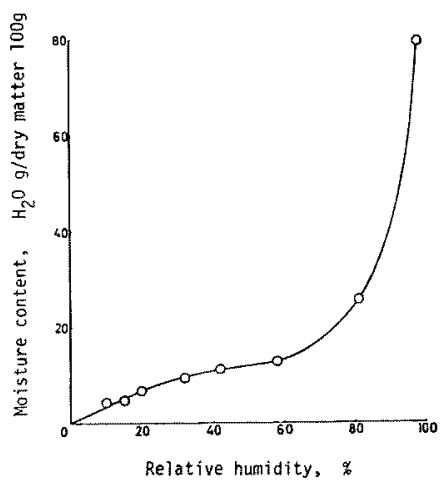

Fig. 2. Moisture sorption isotherm for lyophilized carp myofibrils containing sucrose and PP at $15^{\circ} \mathrm{C}$.

ROCKLAND $^{\text {8) }}$ は温度の美異による $\mathrm{RH}$ の变動がほとん とないものと，大きく变動するものとに塩類溶液を分け ている。Table 1 の中で前者に属するものは $20^{\circ} \mathrm{C}$ から $15^{\circ} \mathrm{C}$ への温度变化て RH $0 \sim 1 \%$ の增加，一つたけ後 者に属する硝酸要鉛は 3\%の增加で，RH $41 \%$ の数值 が与えられている。しかし，同氏の $20^{\circ} \mathrm{C}$ に括ける值は Table 1 のものと同一ではない。この羑異に関しては
LABUZA らワが RH 测定法を比較し, 同じ温度でも测定 法によりRHが相连すること，同じ測定法でも約 $2 \%$ の 実験誤差が生ずると述べて扰り，温度による差よりも測 定法による差あるいは測定誤差の方が大きいと考克られ る。WIISON ${ }^{8)}$ は RH を一定に保てば常温では水分量の 変化は温度によりほとんど変らないと述へてている。また WILSON らのが記述しているよらに水分量の变化は RH $20 \% \sim 60 \%$ では大きなく， RH 約 $42 \%$ を保持する 硝酸覀鉛を用いた場合の温度に上る水分量の差異は小さ いと思われる。

従って，温度による $\mathrm{RH}$ の補正は行わなかった。

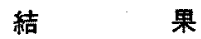

可溶性空素量 Fig. 3 飞示すごとく，RH 98\% 貯蔵 で $1 / 4$ 力月後には激減し，次いで RH $32.3 \%$ 以上で は高湿なほ之速か低下した。RH $20 \%$ 以下の貯蔵で は $1 / 2$ 力月後末でほとんど変らず，その後は 3 力月後ま で低下したが，再び上界した。低湿な汪ど可溶性空素量 恃高く保たれた。

なお，RH $98 \%$ 貯藏では徽が 2 週間後に発生し， 1 カ 月後には著しく繁殖した。それ以外では6カ月間微の発 生は認められなかった。

粘度 Fig. 4 亿示すごとく，RH $98 \%$ 貯蔵では 1/4 カ 月後に RH $32.3 \%$ 以上では高湿なほど速かに低下した。 一方, RH $20 \%$ 以下の貯葴では $1 / 2$ 力月後をではむし 万上昇し，その後は低下したが，RH 10,15\%ては1力 月以降の低下は僅少であった。

ATPase 活性 Fig. 5 に示すごとく，乾燥直後に対照 に比し低下したが， $1 / 4$ カ月拧蔵後に一旦いずれでる增

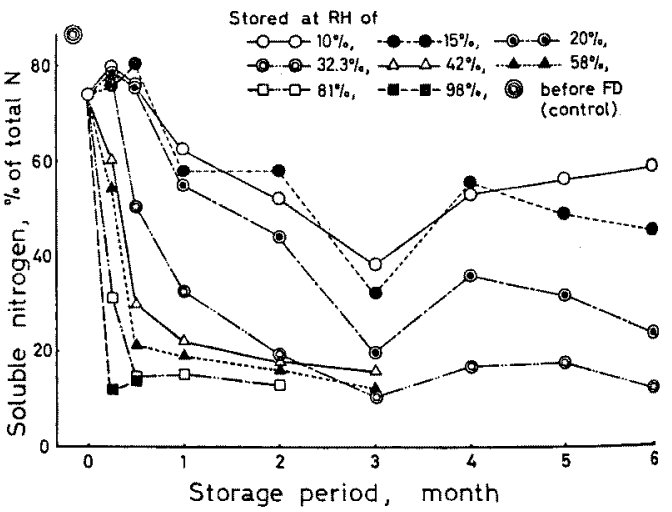

Fig. 3. Effect of relative humidity on the protein denaturation of lyophilized carp myofibrils containing sucrose and PP during storage at room temperature of $15-18.8^{\circ} \mathrm{C}$. Denaturation was estimated by solubility in $0.6 \mathrm{M} \mathrm{KCl}$. 


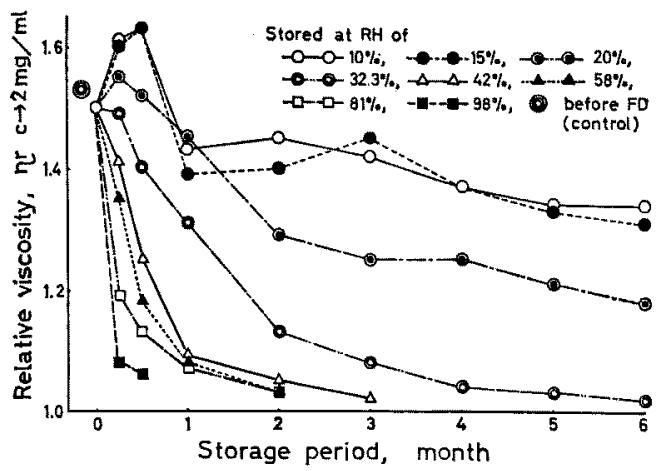

Fig. 4. The same as in Fig. 3. Denaturation was estimated by relative viscosity of $0.6 \mathrm{M} \mathrm{KCl}$ soluble protein.

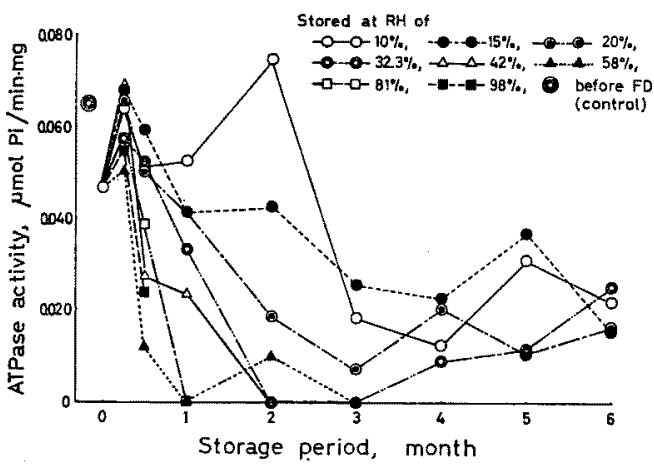

Fig. 5. The same as in Fig. 3. Denaturation was estimated by ATPase activity of $0.6 \mathrm{M} \mathrm{KCl}$ soluble protein.

大した。 RH $58 \%$ 以上の䠉蔵では 1 力月後に， RH $32.3 \%$ 以上では 2 力月後に活性を消失した。しかし, RH $32.3 \%$ をも含めて低湿眝蔵では 6 力月後にも活性 を示した。

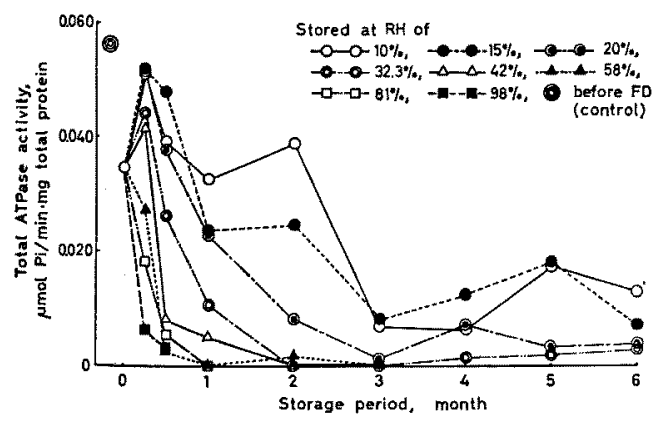

Fig. 6. The same as in Fig. 3. Denaturation was estimated by total ATPase activity of myofibrillar protein.
全 ATPase 活性 Fig. 6 に示すごとく，RH 42\% 以 上の貯蔵では速かに低下し，それより低湿に眝葴するほ ど安定性が高いことが示された。

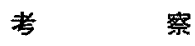

凍結乾燥コイ筋原絨維の眝蔵安定性は RH $42 \%$ 以上 で非常に低く，1/4 1/2 カ月で著しく低下した。 RHが 低いほ上安定性は高かったが，RH 10,15\%間では明ら かな差異は認るられなかっだ。

RH $42 \%$ でこのよらな変化が認められることから， 夏の多湿期たけけでなく冬期においても防湿に対する配慮 の必要性が示惨された。

既に記述”したように，RH 0\%では脂質の酸化によ りタンパク質が間接的に悪化すること，単分子厒の水が 存在する水分域で安定であることが考えられるため， RH 10 98\% について最滴 RH を検討したところ， RH 10〜15\%が好ましいことが示された。しかし，最 適 RH がより低いことも考えられるため，更に検討し た。

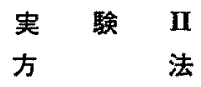

実験 I と同樣に行った。スクロース $5 \%$ と PP 0.2\% とを添加後の筋原繊維の水分は $87.0 \%$ であった。板温 度 $35^{\circ} \mathrm{C}$ で倲結乾燥した。

RH 0 20\%まで5段階に調整しておいたデシヶータ 中にパラフィン紙に包んだ粉末を保管し， $20^{\circ} \mathrm{C}$ に貯蔵 した。ただし，RH 0，5\%はそれぞれ五酸化りン， $69.44 \%$ 硫酸溶液を用いた。粉末の収着等温線は Fig. 7 に示すごとくであった。

なお，硫酸溶液の RH は $25^{\circ} \mathrm{C}$ におりる RH を用い たが，WILSON ${ }^{8)}$ は硫酸溶液の示す RH が温度によりほ とんど変らないことを，ROCKLAND ${ }^{0)}$ 温度に対し鈍感 であることを報告しているため，差異は小さいと考え， 温度による RH の補正は行わなかった。

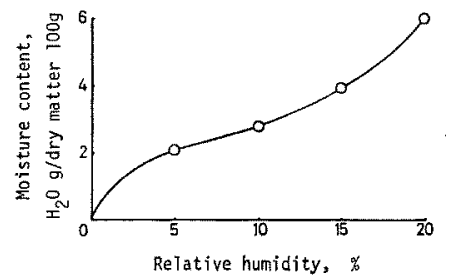

Fig. 7. Moisture sorption isotherm for lyophilized carp myofibrils containing sucrose and PP at $20^{\circ} \mathrm{C}$. 


\section{結}

果

可溶性空素量 Fig. 8 に示すごとく，婻燥直後には対 照に近似したが，その後はRH $20 \%$ 眝蔵でのみ速かに 低下した。RH 0〜15\%では低下がいずれです䇪少で, 1 年後にも高い值を示した。RH 0〜15\%間での差異は 認められなかった。

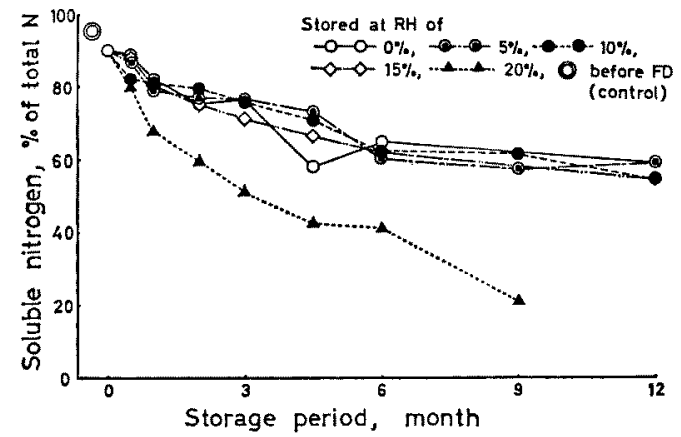

Fig. 8. Effect of relative humidity on the protein denaturation of lyophilized carp myofibrils containing sucrose and PP during storage at $20^{\circ} \mathrm{C}$. Denaturation was estimated by solubility in $0.6 \mathrm{M} \mathrm{KCl}$.

粘度 Fig. 9 に示すごとく，漧燥直後には対照に近似 し，その後も僅かに低下したにすぎなかった。RH 20\% ではやや低い傾向を示したが，貯蔵期間が長くなると他 との差異は認められなかった。

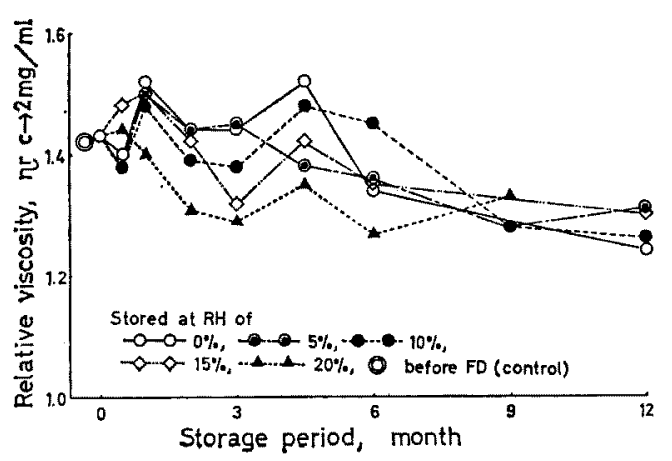

Fig. 9. The same as in Fig. 8. Denaturation was estimated by relative viscosity of $0.6 \mathrm{M} \mathrm{KCl}$ soluble protein.

ATPase 活性 Fig. 10 に示すごとく，乾燥直後には 対照に近似し，眝蔵初期には一旦い寸゙れでる低下した。 RH 0 20\% 間での美異は明らかには認められず，いず れでる1年後にも活性が僅かに低下したにすぎなかっ to

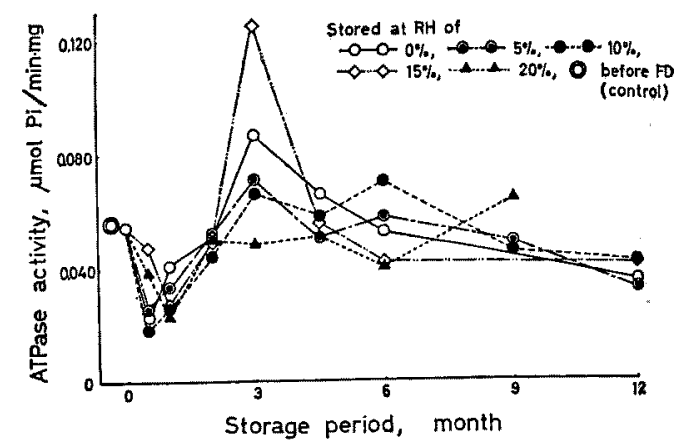

Fig. 10. The same as in Fig. 8. Denaturation was estimated by ATPase activity of $0.6 \mathrm{M} \mathrm{KCl}$ soluble protein.

全 ATPase 活性 Fig. 11 K示すごとく，RH 20\%眝 蔵でのみ低かったが，RH 0〜15\%閒での差巽は明らか には認められず，いずれでも 1 年後にもかなり高い全 ATPase 活性を示した。

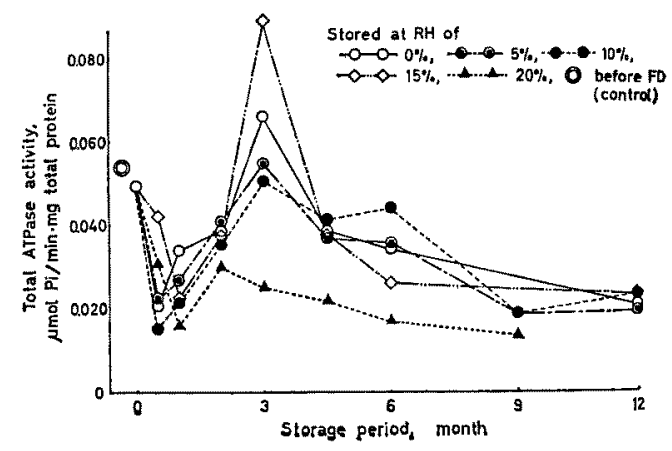

Fig. 11. The same as in Fig. 8. Denaturation was estimated by total ATPase activity of myofibrillar protein.

\section{考察}

倲結乾燥 二1筋原絨維の $20^{\circ} \mathrm{C}$ 貯蔵安定性は RH $20 \%$ でのみ低いのに対して，RH 0 15\%では 1 年間かなり 高く保持された。RH 0〜15\%間では明らかな㓯仕琵 められなかった。

この粉末には乾物当り約 $3 \%$ の脂肪を含及，既に記

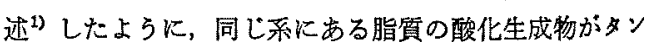
ハク質の変性に関与することは考えられるが, これにつ いては次報で述ぺ。

$$
\text { 実験 III }
$$

実験 I と同様に行った。調䌘した筋原緎維の水分，粗 脂肪，粗タンパク質，粗灰分はそれぞれ90.5, 0.2, 8.2, 


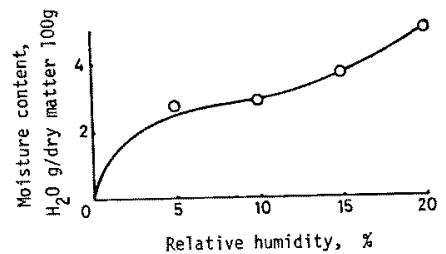

Fig. 12. Moisture sorption isotherm for carp lyophilized myofibrils containing sucrose and $\mathrm{PP}$ at $35^{\circ} \mathrm{C}$.

$1.0 \%$ であった。スクロース $5 \%$ とP $0.2 \%$ とを添加 混合し，板温度 $35^{\circ} \mathrm{C}$ で東結乾燥した。

粉末を実験 II と同じく RH $0 \sim 20 \%$ に保管し， $35^{\circ} \mathrm{C}$ に貯蔵した。粉末 収着等温線は Fig. 12 に示すごとく であった。

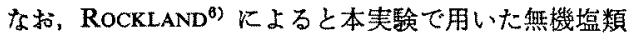
スラリーの $35^{\circ} \mathrm{C}$ での RHは $20^{\circ} \mathrm{C}$ での $\mathrm{RH} よ り 0 \sim 1 \%$ 小さいにすきない。従って，温度による RH の䋠正は 行わなかつた。

\section{結果}

可溶性窒素量 Fig. 13 に示すごとく，RH 20，15\% では貯蔵初期に急速な低下を示し，その後は $4 \frac{1}{2}$ 力月後 まで低下は珰められなかった。RH 0〜10\% 貯蔵では変 動が認められるものの低下は僅少で，かつ，その間での 差異は明らかには認められなかった。

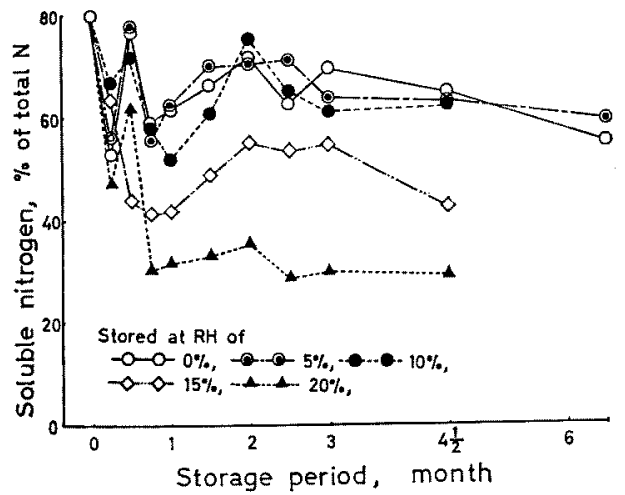

Fig. 13. Effect of relative humidity on the protein denaturation of lyophilized carp myofibrils containing sucrose and PP during storage at $35^{\circ} \mathrm{C}$. Denaturation was estimated by solubility in $0.6 \mathrm{M} \mathrm{KCl}$.

粘度 Fig. 14 に示すごとく，RH 20\% 貯蔵では明ら かに低下し，その他でも貯蔵初期には高湿な汪ど低い傎 向を示したが，期間が長くなると，RH 0〜15\% 間での 差巽は明らかには認められなかった。

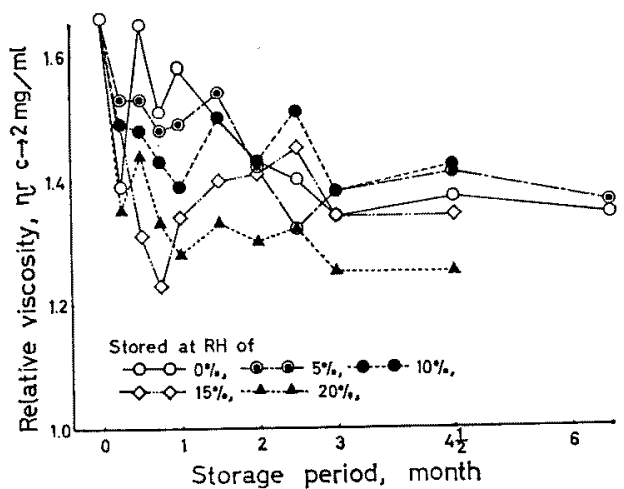

Fig. 14. The same as in Fig. 13. Denaturation was estimated by relative viscosity of $0.6 \mathrm{M}$ $\mathrm{KCl}$ soluble protein.

ATPase 活性 Fig. 15 に示すごとく, ATPase 活性 に関しては盯蔵初期にはいずれでも変動が大きく認めら れたが，その間での差異は認められなかった。期間が脣 くなると，RH 20\% 貯蔵でのみ他よりす低下した。

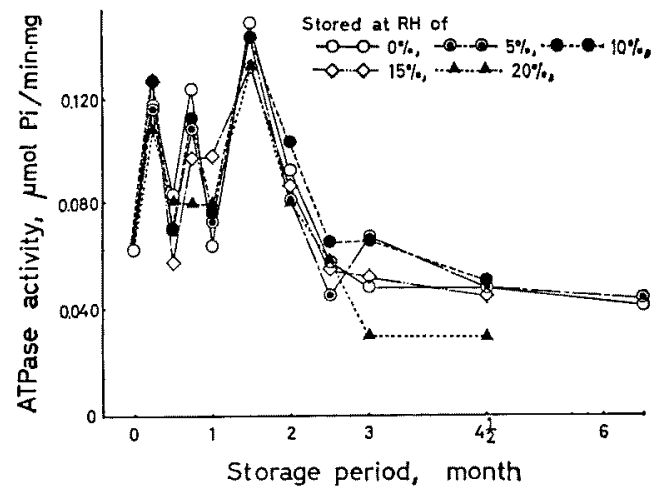

Fig. 15. The same as in Fig. 13. Denaturation was estimated by ATPase activity of $0.6 \mathrm{M}$ $\mathrm{KCl}$ soluble protein.

全 ATPase 活性 Fig. 16 に示すごとく, RH 20\% 眝 蔵では低下が大きく，RH 15\%では次いで低下したが， RH 0〜10\% 間での差異は認められなかった。

\section{考察}

凍結漧燥コイ筋原繊維の $20^{\circ} \mathrm{C}$ 貯藏では RH 0 15\%

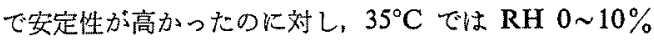
で安定性が高く，本央験からも安全域は低湿にあること が示された。とくに RH $0 \%$ でる単分子圈の水が存在 している時とほぼ同一の安定珄を示すことは次報の酸化 に上る変性と勘案して, スクロースの OH基が水の $\mathrm{OH}$ 基と同様に保護作用を示すとも考えられ興味深い。 


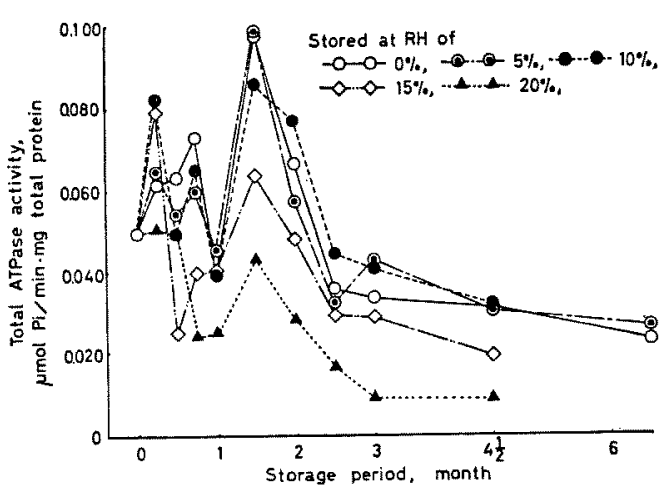

Fig. 16. The same as in Fig. 13. Denaturation was estimated by total ATPase activity of myofibrillar protein.

含水量と高温詝蔵酎性とに関しては倲結乾燥生牛肉 は $2 \%$ 以下の含水量では高温貯蔵耐性があること, ${ }^{10,11)}$ 一方，魚肉では低水分では变性は緩慢であるが高温貯蔵 耐性は小さいことが報告されている。 ${ }^{122}$ 本実験の結果か らはスクロースを添加してある凍結乾燥筋原繊維は低湿 では高温詝蔵耐性があることが示された。

既に考察 ${ }^{2}$ したよらに凍結乾噪直啳にはタンパク質の ひた形成構造は保持されるが，貯蔵中に単分子層の水以 外の易動度の高い水の媒介により極性基が水素結合で飽 和され，また必要に応して結合が切断され，あるいは新 たな相手との結合が生し，タンパク質のひだ形成搆造は 変化すると考えられる。テトラグリシン塩酸構造の変化 が 10 ケのペブチド残基当り約 1 ケの水分子の存在で進 行するという CHIRGADZE ら ${ }^{18)}$ の報告から、この変化は 僅少の水が存在すると起こり得ることが考えられる。同 氏ら ${ }^{13)}$ 酸化とのかかわりあいについては触れて和ら ず，構造の変化は湿度か゚高いほと速いと記載している。 本実験結果から単分子の水が存在していない水分域でも タンパタ質は安定であり，かつ，高温貯藏酎性が增すと 結諭された。

\section{要約}

1.スクロースとPP とを添加した凍結乾燥コイ筋原 繊維を各 RH に䝪蔵し，RH の影響を検討した。
2. 可溶性窒菜量, 粘度, ATPase 活性, 全 ATPase 活性で判定したタンパク質の安定性は RH $10 \sim 98 \%$, $15 \sim 18.8^{\circ} \mathrm{C}$ の室温貯藏では低湿なほど高く， RH $10 \sim$ $15 \%$ では差異が㤎められなかった。

3， $20^{\circ} \mathrm{C}$ 䠉蔵ではRH $0 \sim 15 \%$ で安定性が高く，そ の間の差異は認められなかった。

4. $35^{\circ} \mathrm{C}$ 貯蔵では RH 0 10\% で安定性が高く，そ れより RH が高くなると安定性は低下した。低湿では 高温腙蔵耐性が增すことが示された。

5.このように単分子風の水が存在していない水分域 でる安定であることが示された。

本研究の遂行に当り終始ご蚝篤なるご指導を睗わった 東京水産大学教授田中和夫博士に深く感謝いたします。 また本杗験には東京水産大学学生崎野準悦, 広瀬敏光, 石渡好司, 崔立東, リー・ラム, 戸田裕治, 長沢武人の 七君の協力を得たことを記し，厚く御礼申し上げます。

\section{文献}

1) 松田由美子：日水誌，45, 517-521 (1979).

2) 松田由美子：日水誌，45, 573-579 (1979).

3) N. A. LANGE (ed.): Handbook of Chemistry, 10th ed. McGraw-Hill, New York, 1961, pp. 1420-1423.

4) H. A. Iglesias and J. Chirife: J. Fd. Technol, 11, 109-116 (1976).

5) A. A. TAYLOR: Food Technol, 15, 536-540 (1961).

6) L. B. Rockland: Anal. Chem., 32, 1375-1376 (1960).

7) T. P. Labuza, K. Acott, S. R. Tatini, R. Y. LEE, J. Flink, and W. McCall: J. Food. Sci., 41, 910-917 (1976).

8) R. E. Wilson: J. Ind. Eng. Chem., 13, 326331 (1921).

9) R. E. WILSON and T. FuWA: $J$. Ind. Eng. Chem., 14, 913-918 (1922).

10) L. W. Regier and A. L. TAPPEL: Food Res., 21, 640-649 (1956).

11) L. J. N. Cole: J. Food Sci., 27, 139-143 (1962).

12) 黒木柾吉・木村 進：農産技研誌，8，302-306 (1961).

13) Y.N. Chirgadze and A.M. Ovsepyan: Biopolymers, 11, 2179-2186 (1972). 